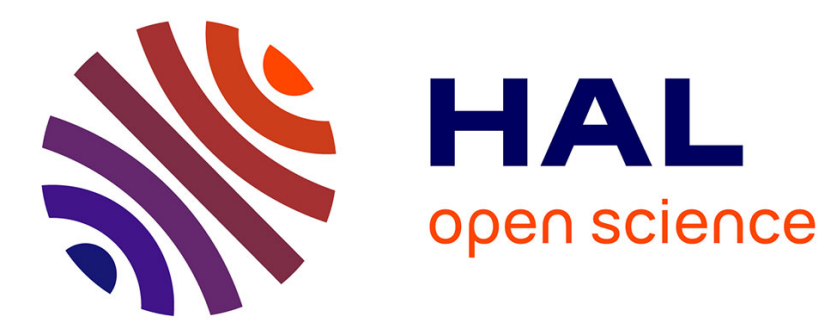

\title{
Building new entities from existing titanium part by electron beam melting: microstructures and mechanical properties
}

Guillaume Mandil, van Thao Le, Henri Paris, Mathieu Suard

\section{- To cite this version:}

Guillaume Mandil, van Thao Le, Henri Paris, Mathieu Suard. Building new entities from existing titanium part by electron beam melting: microstructures and mechanical properties. International Journal of Advanced Manufacturing Technology, 2016, 85 (5), pp.1835 - 1846. 10.1007/s00170-0158049-3 . hal-01230836v2

\section{HAL Id: hal-01230836 \\ https://hal.science/hal-01230836v2}

Submitted on 3 Dec 2015

HAL is a multi-disciplinary open access archive for the deposit and dissemination of scientific research documents, whether they are published or not. The documents may come from teaching and research institutions in France or abroad, or from public or private research centers.
L'archive ouverte pluridisciplinaire HAL, est destinée au dépôt et à la diffusion de documents scientifiques de niveau recherche, publiés ou non, émanant des établissements d'enseignement et de recherche français ou étrangers, des laboratoires publics ou privés. 
"Article retiré par son auteur pour des raisons politiques. II faut attendre l'accord de l'éditeur" 